Meta

Journal des traducteurs

Translators' Journal

\title{
Toward a Science of Translation
}

\section{Brian Harris}

Volume 22, numéro 1, mars 1977

Histoire de la traduction au Canada

URI : https://id.erudit.org/iderudit/003030ar

DOI : https://doi.org/10.7202/003030ar

Aller au sommaire du numéro

Éditeur(s)

Les Presses de l'Université de Montréal

ISSN

0026-0452 (imprimé)

1492-1421 (numérique)

Découvrir la revue

Citer cet article

Harris, B. (1977). Toward a Science of Translation. Meta, 22(1), 90-92.

https://doi.org/10.7202/003030ar

Ce document est protégé par la loi sur le droit d'auteur. L'utilisation des services d'Érudit (y compris la reproduction) est assujettie à sa politique d'utilisation que vous pouvez consulter en ligne.

https://apropos.erudit.org/fr/usagers/politique-dutilisation/
Cet article est diffusé et préservé par Érudit.

Érudit est un consortium interuniversitaire sans but lucratif composé de l’Université de Montréal, l'Université Laval et l'Université du Québec à Montréal. Il a pour mission la promotion et la valorisation de la recherche. https://www.erudit.org/fr/ 


\section{TOWARD A SCIENCE OF TRANSLATION}

The time seems ripe in both French and English to introduce a word meaning « the scientific study of translation 》.

Let us be clear at the start that there is not the remotest intention of usurping «traduction » and "translation » themselves. The reader who wrote to Traduire (87 (II 1976) : 19) ' complaining,

... la traduction me semble être bien plus un art qu'une science... il me paraît inutile de créer un mot nouveau pour désigner cette activité...

had got hold of the wrong end of the stick. The designatum in view is neither the act of translation (l'opération traduisante) nor its product (le texte en langue cible), but the objective study of these phenomena. Similarly we speak \& language \& not « linguistics »; yet the latter word has legitimate use which we all appreciate, and we do not often confuse the two.

Up till recently we have had to make do with analytic terms. Nida's wellknown book «Toward a Science of Translation》 (1964) [my italics in this and following titles] has helped to make that term acceptable; but Catford's title * A Linguistic Theory of Translation \$ (1965) represents the main current, and Nida himself (with Taber) called a later book \& The Theory and Practice of Translation \$ (1969). This trend is matched in French by Mounin's equally well-known

1. I am indebtcd to Fernand Gobeil and Jean Delisle for many of the references. 
"les Problèmes théoriques de la traduction (1963), and in Russian by Fedorov's influential article "Vednie v teoriju perevoda» (1953).

However, scientific tradition, and perhaps a more general principle of economy in language, require that a respectable, well established branch of science be labelled with a synthetic terms of jts own. Of course there is also a strong tradition of breeding such words as hybrids from Greck and Latin stock - or, to usc a more familiar genctic metaphor, classical « roots».

In 1968, a "groupe international de professcurs, d'interprètes et de terminologues » in Brusseis ventured to set up a Centre international d'étude de la traduction. Their manifesto was published in Babel XIV (1968) : 3.143 over the names of R. Goffin, P. Hurbin and J.-M. Vandermeerschen. It is not altogether devoid of the confusion mentioned above, but it includes the following :

La traductiologie [my italics] participe des disciplines linguistiques et extralinguistiques, et le nouveau centre s'est assigné les objectifs suivants :

1) examen de l'état actuel des recherches : enseignement supérieur et organismes internationaux;

2) définition des tâches et coordination des grands thèmes de recherche : terminologie, lexicographie, structuralisme, stylistique comparée (à la fois sous l'angle diachronique et synchronique), histoire de la traduction ;

3) étude des méthodologies spéciales de la traduction et de l'interprétation...

Their word looks correct etymologically : «traductiologie » is derived from the Latin "traductio » just as «traduction 》 is (since 1540 and Etienne Dolet : cf. Dauzat, Nouveau dictionnaire étymologique et historique, Larousse). Does it sound right, though? The Latin should be pronounced «traduct-io » by the classical method, but most people would pronounce the neologism as \& traducsiologie $》$.

In 1973, in ignorance of «traductiologie 》, I myself coined a variant :

Nous conserverons traduction pour l'opération que pratique le traducteur. [Cependant,] si on ne fait pas la iraduction, mais par contrc on en parle, lorsqu'on analyse en tant que linguiste ce qu'est la traduction... nous adopterons traductologie. (In Problèmes de sémantique, Cahiers de linguistique 2. Presses de l'Université du Québec, 134-5.)

It is easy to justify «traductologie » etymologically, since Latin «traductio 》 is itself derived from "traductus $\gg$. Indeed more to the point than the pedantic objection made in the last paragraph to the pronunciation \& traducsiologie 》 is the well-founded feeling that the root is " traduct- $»$ and not «traducti- $»$. In my English publications on the subject since 1973 I have used «translatology », on which more below.

Another suggestion came from Jean Hesse, a retired UNO translator: $\mathrm{He}$ wrote to the Comité d'études des termes techniques français to propose *translatique (Traduire, 86 (I 1976) : 21 and Minutes of 156th Meeting of the Comite). This was immediately subjected to some * critique caustique » from Jean Maillot (ibid, 87 (II 1976) : 19-20) because it evokes «transatlantique » and does not come from the same root as "traduction s. That is a pity, because perhaps we 
could do with «translatique » as well. I see it as a portmanteau word formed out of "translation " and "stylistique » and so meaning « methodical stylistic comparison between source texts and their translations $\geqslant$ - the kind of discussion, for example, which fills Anne Hébert and Frank Scott's Dialogue sur la traduction (à propos du «Tombeau des rois»). But then «traductique » or \& traductostylistique » would be more French. The latter term is analogous to "phonostylistique », which is already current (cf. Dubois, Dictionnaire de linguistique, Larousse, 1973).

Maillot goes on to recommend adoption of

... un terme compréhensible de tous, tel celui de traductologie, déjà employé par des auteurs belges et canadiens, et, par-là même, susceptible d'être admis dans toute la francophonie.

I cannot but agree ! As for «translatology $\gg$ in English, it too is etymologically correct because «translation》 come from a different etymon, the late Latin «translatio » (cf. $O E D$ and Lewis \& Short).

«Traductologie » and «translatogy»: terminologists please take note. I submit that nobody has yet put forward a more felicitous or more concise suggestion for filling this gap in the lexicon of scientific jargon.

BRIAN HARRIS 